\author{
Marta Chmiel-Chrzanowska \\ Uniwersytet Szczeciński, Wydział Humanistyczny \\ email: marta.chmiel-chrzanowska@usz.edu.pl \\ Rafał Fetner \\ Uniwersytet Warszawski, Wydział Historyczny \\ email: rafetner@uw.edu.pl
}

\title{
Problemy i perspektywy badań paleodemograficznych nad kulturą wielbarską na przykładzie cmentarzyska w Kowalewku
}

\author{
Problems and Prospects of Palaeodemographic Research \\ on the Wielbark Culture Exemplified with the Kowalewko Burial Site
}

\begin{abstract}
Abstrakt
W artykule zaprezentowano problemy oraz perspektywy badań paleodemograficznych na cmentarzyskach kultury wielbarskiej na przykładzie stanowiska $12 \mathrm{w}$ Kowalewku. W dotychczasowych pracach paleodemograficznych nad kulturą wielbarską wykorzystywano przede wszystkim tablice wymieralności. Wydaje się jednak, że z uwagi na poważne ograniczenia owej metody i specyfikę danych wejściowych, jakimi są groby, nie można uzyskać tą drogą wiarygodnych wyników. $\mathrm{W}$ niniejszym artykule zaproponowano i poddano krytyce alternatywne rozwiązanie. Analiza przeprowadzona została dla cmentarzyska w Kowalewku z uwagi
\end{abstract}

\begin{abstract}
The article presents problems and prospects of palaeodemographic research on burial grounds of the Wielbark Culture exemplified with Site no 12 in Kowalewko. So far mainly mortality tables have been used in the research. But, as it seems, taking into consideration limitations of that method and the specificity of the input data, i.e. the graves, it is impossible to obtain trustworthy results. The article presents and analyses an alternative solution, exemplified with the burial site in Kowalewko chosen for its representativeness. For comparative reasons the results have been juxtaposed with an analysis of a Medieval skeleton burial site in Kałdus.
\end{abstract}


na jego reprezentatywność. W celach porównawczych wyniki zestawiono z analizą średniowiecznego cmentarzyska szkieletowego w Kałdusie.

\section{Wstęp}

Kultura wielbarska pojawiła się na ziemiach polskich w początkach naszej ery. Skomplikowany, birytualny obrządek pogrzebowy, bogactwo kultury materialnej oraz fakt, że niektórzy badacze dopatrywali się pod tą nazwą substratu gockiego, sprawił, że badania archeologiczne nad tą jednostką trwają intensywnie już od wielu lat.

W historii badań nad kulturą wielbarską wielokrotnie podejmowano próby analiz paleodemograficznych zarówno dla pojedynczych cmentarzysk, jak i dla populacji zbiorczej ${ }^{1}$. Polegały one przede wszystkim na konstrukcji tablicy wymieralności (trwania życia). Metoda ta wymaga przyjęcia złożeń, że populacja podlegająca analizie ma charakter niemaltuzjański i zastojowy. Oznacza to, że liczba rodzących się dzieci równa jest liczbie zmarłych oraz że populacja ta jest zamknięta na migracje ${ }^{2}$. Tego typu podejście krytykowane jest zarówno na łamach literatury polskiej ${ }^{3}$, jak i zagranicznej ${ }^{4}$.

Popularność stosowania metody konstrukcji tablicy wymieralności w badaniach nad społecznością kultury wielbarskiej oraz krytyka wysuwana w stosunku

${ }^{1}$ Judyta Gładykowska-Rzeczycka, „Ludność kultury wielbarskiej w świetle dotychczasowych badań antropologicznych”, w: Problemy kultury wielbarskiej, red. Tadeusz Malinowski (Słupsk: Wyższa Szkoła Pedagogiczna w Słupsku 1981), 163-182; Janusz Piontek, Ludność dorzecza Odry $i$ Wisty od późnej starożytności do średniowiecza. Warunki życia i stan biologiczny. Monografie Instytutu Antropologii UAM 16 (Poznań: Wydawnictwo Instytutu Antropologii UAM, 2014); Kalina Skóra, Struktura społeczna ludności kultury wielbarskiej (Łódź: Wydawnictwo IAiE PAN, 2015).

${ }^{2}$ Maciej Henneberg, „Notes on Reproduction Possibilities of Human Prehistorical Populations”, Przegląd Archeologiczny 41 (1975): 75-89; tenże, ,Reproductive Possibilities and Estimations of the Biological Dynamics of Earlier Human Populations", Journal of Human Evolution 5 (1976), 1: 41-48; tenże, „Proportion of Dying Children In Paleodemographical Studies: Estimation by Guess or by Methodical Approach", Przeglad Archeologiczny 43 (1977): 105-114; Maciej Henneberg, Janusz Ostoja-Zagórski, Janusz Piontek, Jan Strzałko, „Główne założenia teoretyczno-metodyczne oraz możliwości badań biologii populacji pradziejowych w Europie środkowej”, Przegląd Archeologiczny 23 (1975): 187-231; Jan Strzałko, Maciej Henneberg, Janusz Piontek, Wstęp do ekologii populacyjnej człowieka (Poznań: Wydawnictwo Naukowe UAM, 1975); Gładykowska-Rzeczycka, „Ludność”, 163-182.

${ }^{3}$ Edmund Piasecki, „Cmentarzyska w aspekcie demograficznym”, Przeglad Archeologiczny 37 (1990): 5-51.

${ }^{4}$ James W. Wood, Darryl J. Holman, Kathleen A. O'Connor, Rebecca J. Ferrell, „Mortality Models for Paleodemography”, w: Paleodemography. Age Distribution from Skeleton Samples, red. Robert D. Hoppa, James W. Vaupel (Cambridge: SBEA, 2002), 129-168; Isabelle Séguy, Luc Buchet, Arnaud Bringé, Magali Belaigues-Rossard, Paul Beurnier, Nadège Couvert, Carole Perraut, „Model Life Tables for Pre-Industrial Populations: First Application in Palaeodemography”, w: Recent Advances in Palaeodemography Data, Techniques, Patterns, red. Jean-Pierre Bocquet-Appel (Paryż: Springer, 2008). 
do niej stały się dla nas asumptem do napisania niniejszego artykułu. Jego celem jest podsumowanie problematyki badań paleodemograficznych, których źródłem są dane antropologiczne, ze szczególnym uwzględnieniem specyfiki kultury wielbarskiej, a także prezentacja nowej metody, która naszym zdaniem może pozwolić na porównanie demografii cmentarzysk wielbarskich bez odwoływania się do tablic wymieralności.

\section{Problemy wynikające ze specyfiki danych archeologicznych}

Niezwykłe w badaniach nad śmiercią jest to, że pracując na fizycznych szczątkach człowieka staramy się dociekać, w jaki sposób żył i funkcjonował on w środowisku, społeczeństwie, kulturze. Prowadząc zatem studia z zakresu archeologii funeralnej bada się de facto życie, a śmierć jest jedynie jego zakończeniem. Analizując zagadnienia śmierci z tej perspektywy, ważna jest formuła postrzegania śmierci nie tylko przez daną społeczność, ale również przez samego badacza ${ }^{5}$. Informacje na temat życia i funkcjonowania przeszłych społeczności przepuszczone zostają przez swego rodzaju filtr, który określić można funeralnym. Pogrzeb i wydarzenia mu towarzyszące niosą ze sobą wiele znaczeń, które współcześnie mogą być nieczytelne. Samo przygotowanie pogrzebu i postępowanie ze zmarłym mogło trwać niekiedy bardzo długo i zapewne znaczna część obrzędów obecnie nie jest manifestowana w źródłach archeologicznych ${ }^{6}$. Decydujące znaczenie ma również koncepcja eschatologiczna realizowana przez daną społeczność oraz fakt, że to ona normuje prawa i zasady, według których postępuje grupa. Rytuał pogrzebowy ma bowiem wpływ na stan zachowania materiału kostnego, a tym samym na stan danych podlegających analizie przy okazji badań paleodemograficznych.

Równie istotne są problemy wynikające $\mathrm{z}$ samych analiz antropologicznych, których podstawowym zadaniem - z punktu widzenia archeologii - będzie określenie struktury społeczności, czyli dookreślenie wieku i płci zmarłych pochowanych na cmentarzyskach. W takich wypadkach badacz trafia na wiele problemów związanych $\mathrm{z}$ różnym stanem zachowywania materiału kostnego czy też z właściwą eksploracją, dokumentacją i przechowaniem szczątków kostnych, co w istotny sposób może utrudnić prace antropologiczne?

\footnotetext{
5 Jacek Woźny, „Symbolika śmierci i rytuałów pogrzebowych w kulturach wczesnotradycyjnych na ziemiach polskich”, w: Popiót i Kość. Funeralia Lednickie - spotkanie 4, red. Jacek Wrzesiński (Sobótka-Wrocław: Wydawnictwo Oddziału Wielkopolskiego SNAP, 2002), 57.

${ }^{6}$ Marta Chmiel-Chrzanowska, Michał Adamczyk, „O śmierci bez przesady: próba zastosowania podejścia technologicznego w archeologicznych badaniach nad śmiercią", Materiaty $\mathrm{Za}$ chodniopomorskie. Nowa Seria 9 (2015), 1: 7-32.

7 Judyta Gładykowska-Rzeczycka, „Badania antropologiczne źródłem wiedzy o obrządku pogrzebowym", w: Popiót i Kość, 109-110; Simon Mays, Archaeology of Human Bones
} 
Badania paleodemograficzne prowadzone na podstawie wyników prac archeologicznych oraz antropologicznych nastręczają również wielu problemów metodycznych. W przypadku tego typu analiz kluczowe znaczenie będzie mieć zarówno struktura analizowanej próby, jak i dobór metody. Analizy paleodemograficzne prowadzone w oparciu o źródła antropologiczne, choć narażone na wiele błędów, wnieść mogą istotne informacje na temat badanej grupy i pozwalają w przybliżony sposób wnioskować na temat struktur populacji pradziejowych.

Określenie biologicznych kategorii wieku i płci umożliwia podjęcie próby analiz z zakresu paleodemografii. Dzięki zestawieniu ilości obserwowanych jednostek jesteśmy w stanie próbować oszacować dynamikę danej populacji ${ }^{8}$. Problemem w takich sytuacjach jest jednak brak określonych kategorii wiekowych w materiale antropologicznym, spowodowany czynnikami kulturowymi. Przykładem może być chowanie nowonarodzonych dzieci poza głównym obszarem cmentarzyska, co zapewne, prócz wielu innych czynników, tłumaczyć może niedoreprezentację najmłodszych dzieci na cmentarzyskach. W pewnych kulturach dzieci były porzucane bez pochówku, topione lub chowane na odrębnych cmentarzach. Przykładowo, w Skandynawii praktykowano tzw. wynoszenie ${ }^{9}$, polegające na pozostawianiu niechcianych lub chorych dzieci w odludnym miejscu, by tam zginęly. Zwyczaj ten stosowany był na Islandii jeszcze po przyjęciu chrześcijaństwa ${ }^{10}$. W takim wypadku część danych zostaje utracona, co w sposób istotny wpływa na dalsze wyniki badań z zakresu paleodemografii. W kulturze wielbarskiej również obserwujemy pewną niedorepreznetację grobów dziecięcych. $Z$ jednej strony owo zjawisko thumaczyć mogą czynniki związane z zachowaniem szczątków ludzkich oraz niedoskonałością metod badawczych antropologii fizycznej i archeologii. Z drugiej jednak strony nie można wykluczyć również przyczyn mających swe źródło w kulturze. Niewykluczone, że dzieci w tym wieku mogły być chowane również wśród pól i lasów, generalnie poza strefą użytkową ${ }^{11}$.

(London-New York: Routledge, 2002), 17-20; Megan A. Perry, „Redefining Childhood through Bioarchaeology: Toward Archaeological and Biological Understanding of Children in Antiquity", Archaeological Papers of the American Anthropological Association 15 (2005), 1: 89-91.

${ }^{8}$ Piasecki, „Cmentarzyska”; Jan Strzałko, „Ekologia populacji ludzkich”, w: Ekologia populacji ludzkich. Środowisko człowieka w pradziejach, red. Jan Strzałko, Janusz Ostoja-Zagórski (Poznań: Wydawnictwo Naukowe UAM, 1995), 68-69.

${ }^{9}$ Edda Poetycka, przetłumaczyła ze staroislandzkiego Apolonia Załuska-Strömberg (Wrocław: Zakład Narodowy im. Ossolińskich, 1986).

${ }_{10}$ Tamże, przypis 15; Saga o Egilu, przetłumaczyła ze staroislandzkiego Apolonia Załuska-Strömberg (Poznań: Zakład Narodowy im. Ossolińskich, 1972).

${ }^{11}$ Katarzyna Czarnecka, Struktura spoleczna ludności kultury przeworskiej. Próba rekonstrukcji na podstawie źródet archeologicznych i analizy danych antropologicznych z cmentarzyska (Warszawa: Państwowe Wydawnictwo Rolnicze i Leśne, 1990); Renata Madyda-Legutko, Juyta Rodzińska-Nowak, Joanna Zagórska-Telega, „Pochówki dzieci z cmentarzyska kultury przeworskiej w Opatowie, stan. 1, woj. śląskie - próba interpretacji, w: Dusza maluczka, a strata 
W kulturze wielbarskiej notuje się również niższą liczbę pochówków mężczyzn niż kobiet na cmentarzyskach ${ }^{12}$. Dysproporcja między grobami kobiecymi a męskimi na cmentarzyskach wielbarskich może mieć różne podłoże. $Z$ jednej strony przyczyn takiego stanu rzeczy dopatrywać się można w braku kulturowych wyznaczników grobów męskich, a z drugiej - w różnej trafności metod określania płci biologicznej. Nie możemy wykluczyć, że wśród grobów, dla których nie udało się określić płci, zwłaszcza grobów ciałopalnych, przeważają pochówki męskie. Jednakże istnieje również druga możliwość, która z powodu braku danych nie może być ani przyjęta, ani odrzucona. Część mężczyzn mogła być chowana poza obrębem głównego cmentarzyska, np. w miejscu swojej śmierci, lub w sposób, który nie jest czytelny archeologicznie.

Birytualny obrządek pogrzebowy charakterystyczny dla kultury wielbarskiej ma znaczny wpływ na stopień zachowania szczątków ludzkich, a przez to możliwości badawcze. W wyniku spalania dochodzi do utraty masy kości (przede wszystkim frakcji organicznej), znacznego rozdrobnienia i zmian w strukturze krystalicznej. Spalone kości podlegają demineralizacji odmiennie od kości, które nie zostały poddane działaniu temperatury. Sposób przygotowania stosu i rodzaj wykorzystanego drewna wpływają na wysokość temperatury uzyskanej w procesie kremacji, a przebieg rytuału spalania decyduje o czasie ekspozycji na wysoką temperaturę. Bardzo wysoka temperatura, a także długi czas ekspozycji, powodują bardzo dobre przepalenie szczątków ludzkich, prowadząc do deformacji i rozdrobnienia ${ }^{13}$. Dalsze rozdrobnienie może mieć miejsce podczas zbierania i depozycji szczątków w popielnicy bądź jamie. Co więcej, wyniki badań eksperymentalnych wskazują, że jedynie około $40-60 \%$ kości po spaleniu umieszczanych było $\mathrm{w}$ grobie ${ }^{14}$. Prócz tego kości złożone w popielnicy są mniej narażone na działanie procesów podepozycyjnych i środowiskowych niż kości złożone w ja$\mathrm{mie}^{15}$. Ze względu na znaczne rozdrobnienie, deformacje i zły stan zachowania kości ciałopalnych, wnioskowanie o strukturze paleodemograficznej populacji

ogromna. Funeralia Lednickie - spotkanie 6, red. Wojciech Dzieduszycki, Jacek Wrzesiński (Poznań: Wydawnictwo Oddziału Wielkopolskiego SNAP, 2004), 199-215; Dorothy Watts, Boudicca's Heirs. Women in the Early Britain (London, New York: Routledge, 2005).

${ }_{12}$ Zob. np. Pruszcz Gdański stan. 10, Kowalewko stan. 12, por. Skóra, Struktura.

${ }^{13}$ Steven A. Symes, Christopher W. Rainwater, Erin N. Chapman, Desina R. Gipson, Andrea L. Piper, „Patterned Thermal Destruction of Human Remains in Forensic Setting”, w: The Analysis of Burned Human Remeins, red. Christopher W. Schmidt, Steven A. Symes (Amsterdam, Boston, Heidelberg, London, New York, Paris, San Diego, San Francisco, Singapore, Sydney, Tokyo: Academic Press, 2008), 15-60.

${ }^{14}$ Mike P. Pearson, Archaeology of Death and Burial (Phoenix, Mill, Thrupp, Stroud, Gloucestershire: Texas A\&M University Press College Station, 1999), 7.

15 Janusz Piontek, „Wpływ procesu kremacji na morfologię kości szkieletu ludzkiego. Wyniki badań eksperymentalnych”, w: Popiót i Kość, 102-103. 
jest obarczone bardzo dużym błędem ${ }^{16}$. Co więcej, w przypadku kultury wielbarskiej trudno jest powiedzieć, komu przysługiwało ciałopalenie i dlaczego, oraz jak duży wpływ wywiera to na wyniki badań paleodemograficznych.

Innym czynnikiem wpływającym na stan zachowania szczątków ludzkich jest rodzaj gleby, w której pochowani zostali zmarli. Materiał kostny bardzo źle zachowuje się w glebach mających niskie pH, wynoszące ok. 3,5 (gleby kwaśne). Ogromne znaczenie mają również wszelkiego rodzaju grzyby i bakterie, gdyż wytwarzane przez nie środowisko kwasowe wpływa na degradację kolagenu zawartego w kości. Ponadto, stanowiska wielbarskie często znajdują się na piaskach. Ten rodzaj gleby charakteryzuje się wysoką przepuszczalnością wody, co istotnie wpływa na stan zachowania szczątków ludzkich ${ }^{17}$.

Pewnych problemów z punktu widzenia badań archeologicznych nastręczać mogą ogólnie formułowane w antropologii kategorie wiekowe, a także ich niejasne definicje. Zakres czasowy kategorii wiekowych oznaczonych w ramach wieku fizjologicznego różnić się może w zależności od autora i publikacji, np. kategoria senilis w niektórych publikacjach rozpoczyna się już od 50. roku życia, w innych natomiast od 55. roku ${ }^{18}$. W takiej sytuacji prowadzenie rozważań paleodemograficznych jest utrudnione. Dodatkowo, analizy paleodemograficzne realizowane są w oparciu o wiek fizjologiczny, który nie musi być tożsamy z wiekiem kulturowym, czyli postrzeganiem danego osobnika przez grupę jako dziecko, dorosłego itp., co w sposób istotny może utrudnić późniejsze wnioskowanie na temat jej struktur społecznych.

\section{Określenie prawdopodobieństwa zgonu}

W niniejszym artykule wykorzystano metodę pozwalającą na oszacowanie prawdopodobieństwa zgonu (q) zaproponowaną przez Isabelle Séguy i in..$^{19} \mathrm{i}$ będącą rozwinięciem metody Jean-Pierre'a Bocqueta i Claude'a Masseta ${ }^{20}$. Jej autorzy

${ }^{16}$ Steven A. Symes, Christopher W. Rainwater, Erin N. Chapman, Desina R. Gipson, Andrea L. Piper, „Patterned Thermal Destruction of Human Remains in Forensic Setting”, w: The Analysis of Burned Human Remeins, 15-60.

${ }_{17}$ Mays, Archaeology, 17-20.

${ }_{18}^{18}$ Mary E. Lewis, The Bioarchaeology of Children. Perspectives from Biological and Forensic Anthropology, Cambridge (New York, Melbourne, Madrid, Cape Town, Singapore, São Paulo: Cambridge, 2007), 1-2; Siân Halcrow, Nancy Tayles, „The Bioarchaeological Investigations of Childhood and Social Age: Problems and Prospects", Journal of Archaeological Method and Theory 15 (2007): 193-197; Kristen Hawkes, „The Grandmother Effect”, Nature 428 (2004): 128-129; Fredrik Fahlander, „Subadult or Subaltern? Children as Serial Categories”, w: (Re)Thinking the Little Ancestor: New Perspectives on the Archaeology of Infancy and Childhood, BAR 2271M, red. Mike Lally, Alison L. Moore (Oxford: British Archaeological Reports, 2011), 5.

${ }^{19}$ Séguy i in., „Model”.

${ }^{20}$ Jean-Pierre Bocquet-Appel, „Claude Masset, Estimateurs enpaléodémographie”, L'Homme 17 (1977), 4: 65-90; Jean-Pierre Bocquet-Appel, Claude Masset, „Paleodemography: Expectancy 
wyszli z założenia, że szczątki ludzkie nie pozwalają na uzyskanie wiarygodnej informacji o wieku osobników, szczególnie dorosłych, a zatem i na wyznaczenie współczynników paleodemograficznych niezbędnych do zbudowania tablicy wymieralności, takich jak prawdopodobieństwo zgonu w danym wieku. Możliwe jest jednak wykorzystanie wskaźników paleodemograficznych, które można stosunkowo łatwo oszacować i na tej podstawie uzyskać informacje na temat struktury demograficznej populacji.

Do opracowania metody, I. Séguy i in. ${ }^{21}$ posłużyli się 292 tablicami wymieralności społeczeństw pre-industrialnych (XVI - pocz. XX w.) z całego świata, które były pozbawione dostępu do nowoczesnej medycyny. W badaniach założono, że struktura wymieralności takich społeczeństw będzie charakteryzowała się wysoką umieralnością najmłodszych dzieci oraz stosunkowo wysoką umieralnością osobników młodocianych. Dalsza oczekiwana przeciętna długość życia przy narodzinach będzie niska i podobna do tej w wieku 20 lat. Płodność natomiast będzie zaledwie powyżej stopy zastąpienia.

Określenie płci dzieci na podstawie szczątków kostnych jest mało wiarygodne, zatem na potrzeby badań bioarcheologicznych opracowano model dla obu płci, oparty na 167 tablicach wymieralności. Jako dane wejściowe modelu wykorzystano wskaźniki: juvenility index $\left(\mathrm{JI}=\mathrm{D}_{5-14} / \mathrm{D}_{20-\omega}\right), \mathrm{P}\left(\mathrm{P}=\mathrm{D}_{5-19} / \mathrm{D}_{5-\omega}\right)$ oraz średni wiek osobników powyżej 20. roku życia $\left(\mathrm{a}_{20}\right)^{22}$.

Zdaniem I. Séguy i in. ${ }^{23}$ wykorzystanie współczynników JI oraz P pozwala na ominięcie problemu niedoszacowania liczby dzieci na cmentarzysku, ponieważ do ich obliczenia wykorzystywana jest liczba dzieci powyżej 5. roku życia. Co więcej, wskaźniki te oparte są na kategoriach wieku łatwo rozpoznawalnych w materiale kostnym, zatem prawdopodobieństwo przypisania osobnika do niewłaściwej grupy wiekowej jest małe. Znacznie bardziej problematyczne jest określenie średniego wieku osobników dorosłych.

Oszacowanie tego współczynnika na podstawie wyznaczonych wiekiem biologicznym przedziałów będzie nieprecyzyjne, chociażby ze względu na ich szeroki zasięg. Na uwadze należy mieć jednak, że I. Séguy i in. ${ }^{24}$ zaproponowali obliczenie średniej wieku na podstawie analizy obliteracji szwów czaszki. Szacowanie wieku na podstawie jednego tylko wyznacznika wydaje się dość dyskusyjne, zwłaszcza że obliteracja szwów czaszkowych została ostatnio zdyskredytowana jako metoda

and False Hope", American Journal of Physical Anthropology 99 (1996): 571-583.

${ }^{21}$ Séguy i in., „Model”, 85.

22 Tamże.

23 Tamże.

${ }^{24}$ Séguy i in., „Model”. 
określania wieku ${ }^{25}$. W tym punkcie najmocniej rysuje się różnica między paleodemografią historyczną bazującą na źródłach pisanych a bioarcheologią, której analizy oparte są o materiał kostny. Kwestią otwartą pozostaje, w jakim stopniu współczynniki paleodemograficzne obliczone na podstawie tablic wymieralności populacji preindustrialnych znajdą odzwierciedlenie $\mathrm{w}$ oszacowaniach na podstawie kości ludzkich. Pomimo zastosowania najbardziej precyzyjnych metod określania wie$\mathrm{ku}, \mathrm{np}$. metody opartej na rozwoju uzębienia, otrzymany wiek będzie zawierał się w przedziałach dwu-, trzyletnich. Gdy użyte zostaną metody gorzej skorelowane z wiekiem, np. analizy zrostu szwów czaszkowych, mogą to być przedziały nawet trzydziestoletnie, nie pozwalając na precyzyjne określenie wieku osobnika.

Oszacowane tą metodą prawdopodobieństwo zgonu w różnym stopniu koreluje z modelem opracowanym na podstawie wyselekcjonowanych tablic. Według autorów metody, współczynniki JI oraz P najlepiej sprawdzają się dla dzieci do 15. roku życia, natomiast średnia wieku osobników dorosłych - dla osobników między 15. a 55. rokiem życia. Korelacja współczynników z prawdopodobieństwem zgonu osobników starszych jest niska. Co więcej, ma ona tendencję do zawyżania prawdopodobieństwa zgonu dla grup powyżej 55. roku życia ${ }^{26}$.

Podstawową zaletą wykorzystanej metody jest możliwość zastosowania jej do już opublikowanych danych. Jednak w tym wypadku należy z góry założyć, że analizowana populacja cechuje się preindustrialną strukturą demograficzną, jak to opisano powyżej.

\section{Materiały i metody}

W analizie wykorzystano birytualne cmentarzysko kultury wielbarskiej w Kowalewku, stanowisko 12 (powiat Oborniki). Wydaje się, że jest to jedno z najbardziej odpowiednich stanowisk do badań z punktu widzenia celu pracy. Przede wszystkim zostało ono w całości rozpoznane wykopaliskowo, zatem dysponujemy informacjami o całości populacji, która została na nim pochowana; przeważają na nim pochówki szkieletowe. Co więcej, ekspertyzy antropologiczna i archeologiczna zawierały względnie dokładne określenie wieku w momencie śmierci osobników pochowanych w Kowalewku ${ }^{27}$.

${ }^{25}$ Alicja Budnik, „Identyfikacja ludzi na podstawie materiałów szkieletowych - pewność czy prawdopodobieństwo? O możliwościach i ograniczeniach badań", w: Królowie, biskupi, rycerze $i$ chtopi-identyfikacja zmartych. Funeralia Lednickie - spotkanie 16, red. Wojciech Dzieduszycki, Jacek Wrzesiński (Poznań: Wydawnictwo Wielkopolskiego Oddziału SNAP, 2004), 29-33.

${ }^{26}$ Séguy i in. „Model”, 95.

${ }^{27}$ Tomasz Skorupka, Kowalewko 12 cmentarzysko birytualne ludności kultury wielbarskiej (od połowy I w n.e. do początku III w n.e.) (Poznań: Muzeum Archeologiczne w Poznaniu, 2001). 
Z uwagi na problemy, jakie pojawiają się przy określaniu płci i wieku zmarłych pochowanych w obrządku ciałopalnym, w analizie wykorzystano jedynie zarejestrowane na stanowisku groby szkieletowe, dla których możliwe było dookreślenie wieku. Łączna próba wyniosła 205 osobników. Osobnicy poniżej 20. roku życia stanowili 46\% populacji cmentarzyska. Wśród osobników dorosłych o określonej płci dominowały kobiety. Proporcja mężczyzn do kobiet na tym stanowisku wynosiła 0,5 . Dalsza oczekiwana przeciętna długość życia w momencie narodzin $\left(\mathrm{e}_{0}\right)$ wynosiła 18,3 roku, a w wieku 20 lat $\left(\mathrm{e}_{20}\right)$ 14,8.

Wykres. 1. Struktura populacji z cmentarzyska w Kowalewku dla grobów szkieletowych

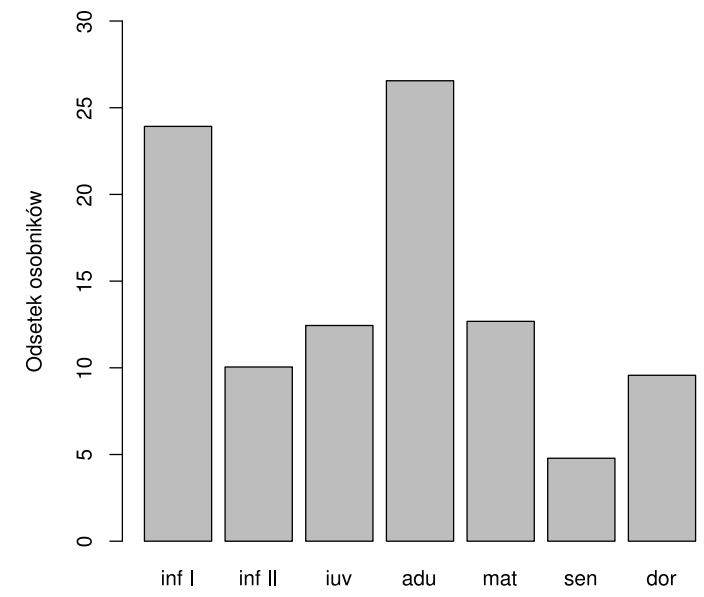

Uwaga: wiek podano w kategoriach biologicznych (inf I - infans I, inf II - infans II, iuv - iuvenis, adu - adultus, mat - maturus, sen - senilis) wraz z kategorią zbiorczą dor - osobnicy dorośli.

Źródło: opracowanie własne na podstawie Tomasz Skorupka, Kowalewko 12. cmentarzysko birytualne ludności kultury wielbarskiej (od połowy I w n.e. do początku III w n.e.) (Poznań: Muzeum Archeologiczne w Poznaniu, 2001).

Analogiczną analizę przeprowadzono dla szkieletowego, średniowiecznego cmentarzyska w Kałdusie (powiat chełmiński) ${ }^{28}$. Głównym celem tego kroku była chęć porównania wyników analiz paleodemograficznych z Kowalewka z wynikami analiz dla cmentarzyska, na którym zmarli chowani byli jedynie w obrządku szkieletowym. Dodatkowo oba cmentarzyska zlokalizowane są na podobnym obszarze, a wyniki badań antropologicznych zostały opublikowane w całości. W analizie

${ }^{28}$ Wojciech Chudziak, red., Wczesnośredniowieczne cmentarzysko szkieletowe w Kałdusie (stanowisko 4) (Toruń: Wydawnictwo UMK, 2010). 
przeprowadzonej dla cmentarzyska w Kałdusie ujęto 467 osobników. Osobnicy poniżej 20. roku życia stanowią $37 \%$ ogółu ludności pochowanej na stanowisku. Wśród osobników dorosłych o określonej płci dominowały kobiety, stosunek mężczyzn do kobiet wyniósł w Kałdusie 0,8 . Dalsza oczekiwana długość życia w momencie narodzin $\left(\mathrm{e}_{0}\right)$ wynosiła 20,6 roku, a w wieku 20 lat $\left(\mathrm{e}_{20}\right)$ wynosiła 15,9 roku.

Rysunek 1. Lokalizacja cmentarzyska w Kowalewku i w Kałdusie

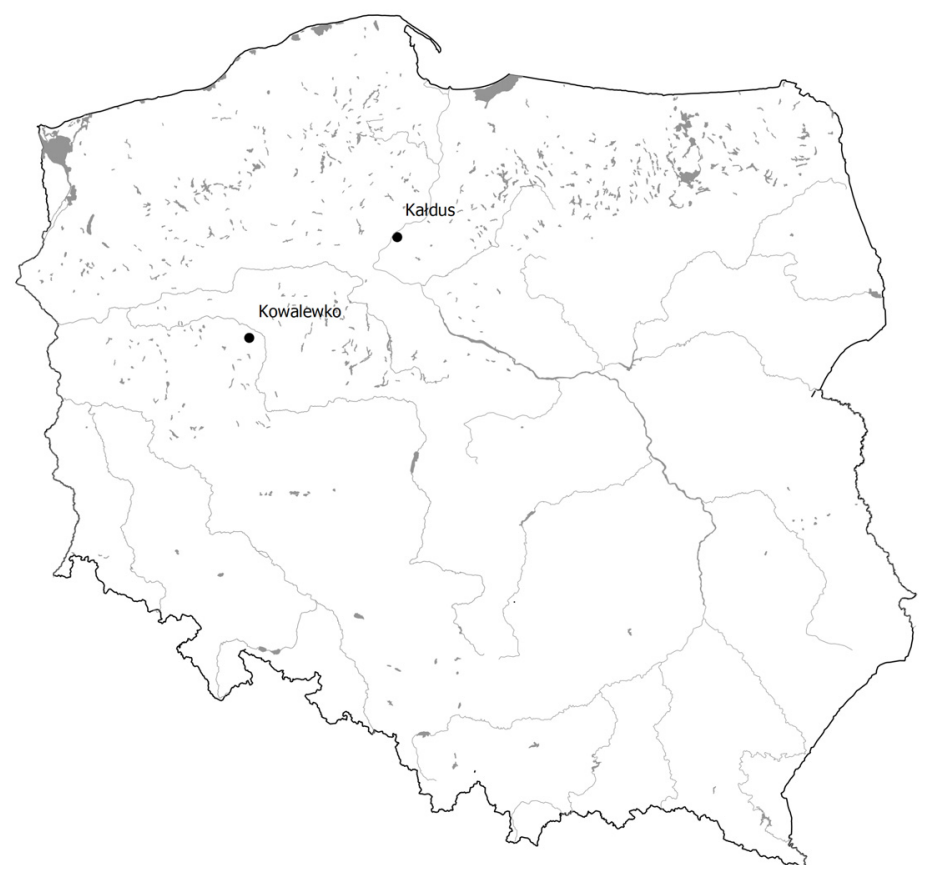

Źródło: jak przy wykresie 1.

Na podstawie opublikowanych danych paleodemograficznych dla cmentarzysk w Kowalewku i Kałdusie zostały obliczone wskaźniki JI, P oraz a ${ }_{20}^{29}$. Prawdopodobieństwo zgonu zostało oszacowane dla populacji stacjonarnej $(\mathrm{r}=0)$ oraz populacji o przyroście naturalnym niewiele większym niż stopa zastąpienia $(\mathrm{r}=0,0025)$. Ponadto oszacowane zostało prawdopodobieństwo zgonu dzieci do 5 . roku życia ${ }_{5} \mathrm{q}_{0}$, według wzoru zaproponowanego przez Isabelle Séguy i Luca Bucheta ${ }^{30}$.

29 Tamże.

${ }^{30}$ Isabelle Séguy, Luc Buchet, Handbook of Paleodemography (New York: Springer, 2013), 130. 
W celu porównania wyników z tablicami wymieralności obliczono dalszą oczekiwaną długość życia w momencie narodzin, jak i w wieku 20 lat, na podstawie oszacowanego prawdopodobieństwa zgonu $\left(\mathrm{q}_{\mathrm{x}}\right)$ dla populacji stacjonarnej $(\mathrm{r}=0)$.

\section{Wyniki}

Rezultaty analizy zaprezentowano w tabeli 1 i zilustrowano wykresami 2 i 3. Współczynniki wyliczone dla stanowiska w Kowalewku wynoszą: $\mathrm{JI}=0,286, \mathrm{P}=$ 0,337 oraz $\mathrm{a}_{20}=34,2$. Prawdopodobieństwo zgonu dzieci w wieku 0 -5 lat wynosi $548 \%$ dla populacji stacjonarnej i $490 \%$ dla populacji stabilnej.

Tabela 1. Wyniki oszacowania $\mathrm{q}_{\mathrm{x}}$ (podane $\mathrm{w}$ promilach) na podstawie juvenility index, „P indicator” oraz średniego wieku osobników dorosłych $\left(\mathrm{a}_{20}\right)$ dla cmentarzyska w Kowalewku, odpowiednio dla populacji stacjonarnej $(\mathrm{r}=0)$ oraz stabilnej $(\mathrm{r}=0,0025)$.

\begin{tabular}{cccccccccccccc}
\hline \multirow{2}{*}{ Wiek } & \multicolumn{10}{c}{$\mathrm{r}=0$} & \multicolumn{10}{c}{$\mathrm{r}=0,0025$} \\
\cline { 2 - 13 } & \multicolumn{1}{c}{$\mathrm{JI}=0,286$} & $\mathrm{P}=0,337$ & $\mathrm{a}_{20}=34,2$ & $\mathrm{JI}=0,286$ & $\mathrm{P}=0,337$ & $\mathrm{a}_{20}=34,2$ \\
\hline $0-1$ & 316 & 31 & 347 & 41 & $\times$ & $\times$ & $\mathbf{2 9 7}$ & 29 & 356 & 35 & $\times$ & $\times$ \\
$1-4$ & $\mathbf{2 7 4}$ & 36 & 277 & 44 & $\times$ & $\times$ & $\mathbf{2 4 5}$ & 31 & 271 & 39 & $\times$ & $\times$ \\
$5-9$ & 168 & 14 & $\mathbf{2 2 5}$ & 38 & 249 & 93 & 142 & 12 & 203 & 31 & $\mathbf{1 8 9}$ & 71 \\
$10-14$ & 69 & 8 & 86 & 9 & $\mathbf{1 1 9}$ & 28 & 61 & 7 & 83 & 9 & $\mathbf{1 3 1}$ & 30 \\
$15-19$ & $\times$ & $\times$ & $\times$ & $\times$ & 168 & 20 & $\times$ & $\times$ & $\times$ & $\times$ & 197 & 32 \\
$20-24$ & $\times$ & $\times$ & $\times$ & $\times$ & 237 & 28 & $\times$ & $\times$ & $\times$ & $\times$ & 270 & 32 \\
$25-29$ & $\times$ & $\times$ & $\times$ & $\times$ & 283 & 36 & $\times$ & $\times$ & $\times$ & $\times$ & 329 & 41 \\
$30-34$ & $\times$ & $\times$ & $\times$ & $\times$ & 315 & 32 & $\times$ & $\times$ & $\times$ & $\times$ & 374 & 36 \\
$35-39$ & $\times$ & $\times$ & $\times$ & $\times$ & 364 & 32 & $\times$ & $\times$ & $\times$ & $\times$ & 420 & 35 \\
$40-44$ & $\times$ & $\times$ & $\times$ & $\times$ & 417 & 36 & $\times$ & $\times$ & $\times$ & $\times$ & 477 & 40 \\
$45-49$ & $\times$ & $\times$ & $\times$ & $\times$ & 461 & 39 & $\times$ & $\times$ & $\times$ & $\times$ & 522 & 45 \\
$50-54$ & $\times$ & $\times$ & $\times$ & $\times$ & 512 & 45 & $\times$ & $\times$ & $\times$ & $\times$ & 622 & 57 \\
$55-59$ & $\times$ & $\times$ & $\times$ & $\times$ & 608 & 59 & $\times$ & $\times$ & $\times$ & $\times$ & 674 & 67 \\
$60-64$ & $\times$ & $\times$ & $\times$ & $\times$ & 553 & 41 & $\times$ & $\times$ & $\times$ & $\times$ & 640 & 47 \\
$65-69$ & $\times$ & $\times$ & $\times$ & $\times$ & 634 & 44 & $\times$ & $\times$ & $\times$ & $\times$ & 642 & 43 \\
$70-74$ & $\times$ & $\times$ & $\times$ & $\times$ & 766 & 57 & $\times$ & $\times$ & $\times$ & $\times$ & 777 & 63 \\
$75-0$ & $\times$ & $\times$ & $\times$ & $\times$ & 723 & 60 & $\times$ & $\times$ & $\times$ & $\times$ & 790 & 67 \\
\hline
\end{tabular}

Uwaga: wytłuszczono oszacowania o najwyższej korelacji, kursywą oznaczono oszacowania o korelacji mniejszej niż 0,800 .

Źródło: opracowanie własne. 
Wykres. 2. Graficzne zobrazowanie wyników oszacowania $\mathrm{q}_{\mathrm{x}}$ na podstawie juvenility index, „P indicator”
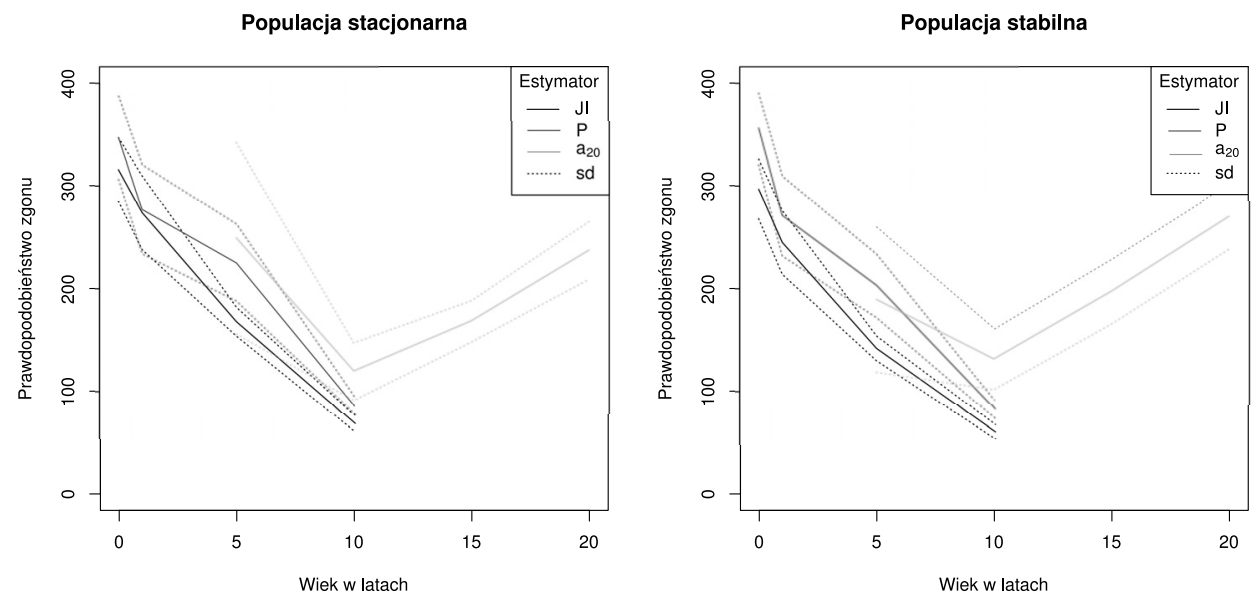

Źródło: jak przy wykresie 1.

Wykres 3. Graficzne zobrazowanie wyników oszacowania $\mathrm{q}_{\mathrm{x}}$ na podstawie średniego wieku w momencie śmierci osobników dorosłych $\left(\mathrm{a}_{20}\right)$.

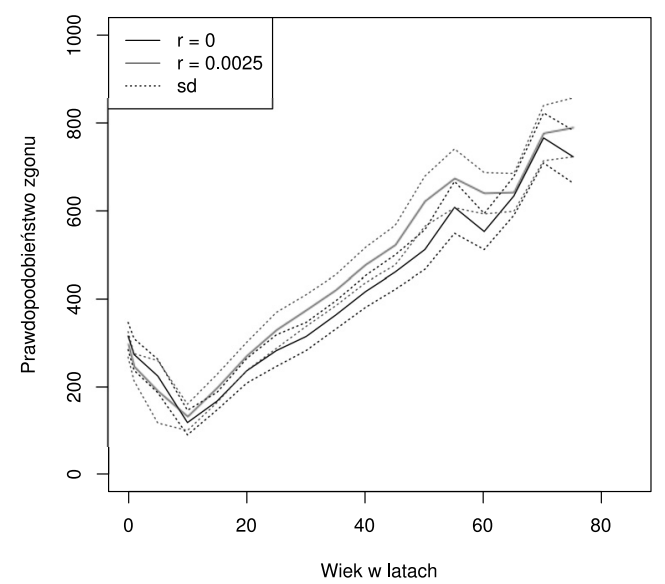

Źródło: jak przy wykresie 1.

Prawdopodobieństwo zgonu noworodka $\left(\mathrm{q}_{0}\right)$ wynosi ok. 300\%o w obu modelach, co wydaje się typowe dla populacji preindustrialnych. W przypadku modelu stacjonarnego prawdopodobieństwo zgonu oparte o JI jest nieznacznie wyższe 
niż w przypadku modelu stabilnego, w przeciwieństwie do modelu opartego o wskaźnik P. Jednakże należy mieć na uwadze fakt, że korelacja tych dwóch współczynników $\mathrm{z}$ wartościami tabel wymieralności została oszacowana na $0,800-0,810$, zatem wyciąganie daleko idących wniosków byłoby przedwczesne. Podobna zależność widoczna jest w przypadku dzieci w wieku 1-9 lat, gdzie prawdopodobieństwo zgonu jest wyższe $\mathrm{w}$ modelu stacjonarnym niż $\mathrm{w}$ stabilnym. Średni wiek osobników dorosłych w momencie śmierci $\left(\mathrm{a}_{20}\right)$ wyliczony dla cmentarzyska w Kowalewku wyniósł 31,4 lat.

Nieco odmienne rezultaty uzyskano w trakcie analizy dla cmentarzyska w Kałdusie (por. tab. 2). Współczynnik JI wynosi $0,221, \mathrm{P}=0,234$, natomiast $\mathrm{a}_{20}$ $=35,9$. Prawdopodobieństwo zgonu noworodków wynosi ok. $285 \%$, natomiast dzieci do 5. roku życia - 474\%o. Jednak struktura zasadniczo nie różni się od struktury stanowiska w Kowalewku. W przypadku stanowiska w Kałdusie zauważalna jest duża zbieżność między prawdopodobieństwem zgonu oszacowanym na podstawie JI i P, większa niż w przypadku Kowalewka.

Tabela 2. Wyniki oszacowania $\mathrm{q}_{\mathrm{x}}$ (podane $\mathrm{w}$ promilach) na podstawie JI, $\mathrm{P}$ oraz $\mathrm{a}_{20}$ dla cmentarzyska w Kałdusie dla populacji stacjonarnej $(\mathrm{r}=0)$

\begin{tabular}{crrrrrr}
\hline \multirow{2}{*}{ Wiek } & \multicolumn{2}{c}{$\mathrm{JI}=0,221$} & \multicolumn{2}{c}{$\mathrm{P}=0,234$} & \multicolumn{2}{c}{$\mathrm{a}_{20}=35,9$} \\
\cline { 2 - 7 } $0-1$ & $\mathrm{q}_{\mathrm{x}}$ & $\mathrm{sd}$ & $\mathrm{q}_{\mathrm{x}}$ & $\mathrm{sd}$ & $\mathrm{q}_{\mathrm{x}}$ & $\mathrm{sd}$ \\
\hline $1-4$ & $\mathbf{2 8 4}$ & 28 & 285 & 34 & $\times$ & $\times$ \\
$5-9$ & $\mathbf{2 3 7}$ & 31 & 219 & 34 & $\times$ & $\times$ \\
$10-14$ & 129 & 11 & $\mathbf{1 3 7}$ & 23 & 220 & 82 \\
$15-19$ & 57 & 6 & 59 & 6 & $\mathbf{1 0 7}$ & 25 \\
$20-24$ & $\times$ & $\times$ & $\times$ & $\times$ & 150 & 18 \\
$25-29$ & $\times$ & $\times$ & $\times$ & $\times$ & 211 & 25 \\
$30-34$ & $\times$ & $\times$ & $\times$ & $\times$ & 251 & 32 \\
$35-39$ & $\times$ & $\times$ & $\times$ & $\times$ & 279 & 28 \\
$40-44$ & $\times$ & $\times$ & $\times$ & $\times$ & 322 & 28 \\
$45-49$ & $\times$ & $\times$ & $\times$ & $\times$ & 369 & 31 \\
$50-54$ & $\times$ & $\times$ & $\times$ & $\times$ & 410 & 35 \\
$55-59$ & $\times$ & $\times$ & $\times$ & $\times$ & 547 & 40 \\
$60-64$ & $\times$ & $\times$ & $\times$ & $\times$ & 512 & 53 \\
$65-69$ & $\times$ & $\times$ & $\times$ & $\times$ & 598 & 38 \\
$70-74$ & $\times$ & $\times$ & $\times$ & $\times$ & 728 & 54 \\
$75-\omega$ & $\times$ & $\times$ & $\times$ & $\times$ & 701 & 58 \\
\hline
\end{tabular}

Uwaga: wytłuszczono oszacowania o najwyższej korelacji, kursywą oznaczono oszacowania o korelacji mniejszej niż 0,800 .

Opracowanie własne. 
Dalsza oczekiwana przeciętna długość życia w momencie narodzin $\left(\mathrm{e}_{0}\right)$ obliczona dla cmentarzyska w Kowalewku na podstawie oszacowanego prawdopodobieństwa zgonu $\left(\mathrm{q}_{\mathrm{x}}\right)$ wynosi 12,6 roku dla populacji stacjonarnej oraz 13 lat dla populacji stabilnej $(\mathrm{r}=0,0025)$. Natomiast dla stanowiska w Kałdusie $\mathrm{e}_{0}=16$ lat $(\mathrm{r}=0)$. Dalsza oczekiwana przeciętna długość życia w wieku 20 lat $\left(\mathrm{e}_{20}\right)$ dla stanowiska w Kowalewku wynosi 13,5 roku $($ dla $r=0)$ oraz 11,8 dla $(r=0,0025)$, w przypadku stanowiska w Kałdusie $\mathrm{e}_{20}=15$ lat.

\section{Dyskusja}

Współczynniki JI oraz P obliczone dla stanowiska w Kowalewku są wysokie w porównaniu do danych modelowych dla $\mathrm{e}_{0}=20$ lat (model „West”) ${ }^{31}$ wynoszących odpowiednio 0,16 i 0,19. Wykraczają również poza wartości dla modeli o wyższej dalszej oczekiwanej długości życia w momencie narodzin. Zdaniem Mary Jackes ${ }^{32}$, w przypadku zbyt wysokich wartości tych współczynników należy ocenić, czy zostało przebadane całe stanowisko i czy w analizie zostały uwzględnione osobniki dorosłe, bez precyzyjnego określenia wieku (tzw. kategoria „,dorosły”). Oba te czynniki zostały spełnione. Jeśli je wykluczyć, wysoka wartość może być wynikiem znacznego wzrostu populacji, choć bywa również spotykana w przypadku profili katastroficznych ${ }^{33}$. Może również wynikać z niedoszacowania badanej populacji. W przypadku kultury wielbarskiej mogłoby to być niedoszacowanie mężczyzn, widoczne również w przypadku stanowiska w Kowalewku. Otwarte pozostaje pytanie, jaka jest proporcja mężczyzn do kobiet wśród osobników poddanych kremacji. Analizy związku między wiekiem zmarłych i płcią a sposobem pochówku (ciałopalenie lub inhumacja) przy użyciu testu $\chi^{2}$ wskazują na brak korelacji między tymi dwiema zmiennymi ${ }^{34}$. W związ$\mathrm{ku} \mathrm{z}$ tym żadna $\mathrm{z}$ kategorii wiekowych lub płciowych nie powinna zostać wyeliminowana $\mathrm{z}$ analiz $\mathrm{z}$ powodu nieuwzględnienia grobów ciałopalnych. Jednak niemal $43 \%$ generalnej liczby grobów miało charakter ciałopalny, a tym samym zostało wyłączonych $\mathrm{z}$ analiz $\mathrm{z}$ uwagi na problemy, jakich tego typu pochówki nastręczają przy określaniu wieku i płci zmarłych. Tutaj na uwadze należy mieć również fakt, że dla $27 \%$ procent zmarłych pochowanych w obrządku szkieleto-

${ }^{31}$ Ansley J. Coale, Paul Demeny, Barbara Vaughan, Regional Model Life Tables and Stable Population (New York, London, Paris: Academic Press, 1983).

${ }^{32}$ Mary Jackes, „Palaeodemography: Problems and Techniques”, w: Skeletal Biology of Past Peoples: Research Methods, red. Shelley R. Saunders, M. Anne Katzenberg (New York: WileyLiss, 1992), 189-224.

${ }^{33}$ Tamże.

${ }^{34}$ Marta Chmiel-Chrzanowska, „Starość w społeczności kultury wielbarskiej”, Przeglad Archeologiczny 64 (2016), 111-131. 
wym na cmentarzysku w Kowalewku nie można było określić wieku z powodu złego zachowania materiału kostnego ${ }^{35}$.

Znacznie niższa liczba grobów mężczyzn ma być jednym z typowych elementów kultury wielbarskiej, zwłaszcza w fazie cecelskiej (od 1 poł. III wieku do okresu wędrówek ludów) ${ }^{36}$. Przykładowo, na cmentarzysku w Cecelach proporcja między grobami kobiecymi a męskimi wyniosła 134 do 55. Jednakże w tym wypadku, dla bardzo dużego odsetka zmarłych - 70\% - niemożliwe było określenie płci. Fakt, że tak znaczny odsetek zmarłych nie ma dookreślonej płci, wynika również z tego, że niemal $35 \%$ zmarłych stanowiły dzieci, dla których określenie płci praktycznie jest niemożliwe. Dla porównania, na cmentarzysku w Pruszczu Gdańskim (stan. 10) proporcja między kobietami a mężczyznami wynosi 71 do 17. Pochówki osób, dla których określenie płci nie było możliwe, wynoszą jedynie $32 \%$, dzieci zaś stanowią zaledwie $7 \%$ generalnej liczby pochowanych zmarłych. Obrządkiem, który dominował na cmentarzysku w Pruszczu Gdańskim (stan. 10), była inhumacja ${ }^{37}$. Dysproporcja między płciami jest wciąż dobrze czytelna.

Jeśli założyć, że część mężczyzn chowana była w sposób nieczytelny dla nas współcześnie i miało to związek z ich statusem społecznym, funkcją realizowaną w ramach grupy czy też rodzajem śmierci, np. w boju, w trakcie wyprawy itp., należałoby spojrzeć na analizowany zbiór z innej perspektywy. Konieczna stałaby się refleksja nad tym, czy liczba grobów osobników dorosłych w próbie nie jest niejako automatycznie zaniżona. Jednocześnie na uwadze należy mieć fakt, że płeć określono jedynie dla $24 \%$ populacji Kowalewka (16\% stanowiły kobiety, 7\% mężczyźni). Zdecydowaną większość pochówków w przypadku obu płci stanowi inhumacja. Dodatkowo 23\% wszystkich grobów stanowią pochówki dzieci. Ewentualny „niedobór” grobów męskich mógłby mieć istotny wpływ na wyniki analiz. Oczywiście są to rozważania hipotetyczne w przypadku cmentarzyska w Kowalewku z uwagi na niski procent osobników, dla których udało się określić płeć.

Porównując stanowisko $12 \mathrm{z}$ cmentarzyskiem szkieletowym w Kałdusie, współczynniki JI i P obliczone dla Kowalewka są wyższe niż analogiczne wskaźniki dla Kałdusa, jednakże również w tym przypadku spotykamy wyższe wartości niż modelowe. Populacja Kałdusa, emporium handlowego o ponadregionalnym

\footnotetext{
${ }^{35}$ Skorupka, Kowalewko.

${ }^{36}$ Jan Jaskanis, Jerzy Okulicz, Kultura Wielbarska (faza cecelska), w: Prahistoria ziem polskich, t. 5: Późny okres lateński i okres rzymski, red. Jerzy Wielowiejski (Wrocław - Warszawa - Kraków - Gdańsk: Zakład Narodowy Imienia Ossolińskich, Wydawnictwo Polskiej Akademii Nauk, 1981), 188-189.

${ }^{37}$ Mirosław Pietrzak, Pruszcz Gdański Fundstelle 10 Ein Gräberfeld der Osywie- und Wielbark-Kultur in Ostpolen (Kraków: Secesja, 1997).
} 
zasięgu $^{38}$, była $\mathrm{w}$ dużym stopniu otwarta na migracje, co niestety umyka analizom paleodemograficznym. Wysoka mobilność ludzka mogła doprowadzić do sytuacji, w której część dorosłych nie jest reprezentowana w materiale archeologicznym. Jak sugeruje stosunek liczbowy mężczyzn do kobiet, niedoszacowanie mężczyzn na cmentarzysku w Kowalewku było większe niż w Kałdusie. Niedoszacowanie to mogło wpłynąć na określenie współczynnika $\mathrm{a}_{20}$, mimo tego średni wiek osobników dorosłych dla obu stanowisk jest podobny.

Populacja z Kowalewka cechowała się wyższym prawdopodobieństwem zgonu $\left(\mathrm{q}_{\mathrm{x}}\right)$ niż populacja $\mathrm{z}$ Kałdusa. Widoczne jest to w każdej kategorii wiekowej, jak również w kategoriach zbiorczych, jak np. ${ }_{5} \mathrm{q}_{0}$. W porównaniu do tabel wymieralności populacji stacjonarnej, metoda Séguy i in. ${ }^{39}$ obniżyła dalszą oczekiwaną długość życia w momencie narodzin o ok. 4 do 5 lat, podczas gdy $e_{20}$ dla obu metod pozostał podobny. Zmiana ta nie jest czysto teoretyczna, ale wpływa na postrzeganie populacji żyjącej, np. przy e $\mathrm{e}_{0} \approx 20$ lat współczynnik reprodukcji brutto oszacowany metodą $\mathrm{McCaa}^{40}$ wynosi ok. 3,2. Oznacza to, że na jedną kobietę przypadałyby średnio trzy córki. W przypadku populacji o e $e_{0}$ wynoszącym 13 lat, jak sugeruje zaproponowana metoda, współczynnik reprodukcji brutto wynosi ok. 5 i średnio pięć córek przypadających na jedną kobietę. Jest mało prawdopodobne, aby jedna kobieta dożywająca końca wieku reprodukcyjnego urodziła średnio pięć córek, a zatem dziesięcioro dzieci.

Alternatywnym wyjaśnieniem dla niskiej dalszej oczekiwanej długości życia jest silny stres środowiskowy. W tym przypadku prawdopodobieństwo zgonu dzieci ${ }_{5} \mathrm{q}_{0}$ oszacowane metodą zaproponowaną przez Séguy i in..$^{41}$ mogłoby spełniać rolę papierka lakmusowego pozwalającego na porównywanie umieralności między populacjami. Prawdopodobieństwo zgonu byłoby wprost proporcjonalne do stresu działającego na daną populację. Jednak wykorzystanie danych paleodemograficznych pociąga za sobą szereg problemów i ograniczeń. Interpretacja $\mathrm{q}_{\mathrm{x}}$ jako poziomu stresu w populacji wymusza przyjęcie założenia, że każdy osobnik podlegał jednakowemu stresowi, co nie jest prawdą. Niestety, heterogeniczność stresu i ryzyka zgonu jest nieuchwytna w badaniach paleodemograficznych opartych o populacje szkieletowe ${ }^{42}$.

${ }^{38}$ Wojciech Chudziak, red., Wczesnośredniowieczny zespół osadniczy w Kałdusie: studia przyrodniczo-archeologiczne (Toruń: Wydawnictwo UMK, 2004).

${ }^{39}$ Séguy i in., ,Model”.

${ }^{40}$ Robert McCaa, „Palaeodemography of Americas. From Ancient Times to Colonialism and Beyond", w: The Backbone of History: Health and Nutrition in the Western Hemisphere, red. Richard H. Steckel, Jerome C. Rose (Cambridge: Cambridge University Press, 2002), 94-124.

${ }^{41}$ Séguy i in., ,Model”.

${ }^{42}$ James W. Wood, George R. Milner, Henry C. Harpending, Kenneth M. Weiss, „The Osteological Paradox: Problems of Inferring Prehistoric Health from Skeletal Samples”, Current Anthropology 33 (1992), 4: 343-370. 
Co więcej, różne poziomy odmiennych stresorów mogą w efekcie manifestować się podobną krzywą prawdopodobieństwa zgonu $\left(\mathrm{q}_{\mathrm{x}}\right)$. Natężenie stresu nie będzie proporcjonalne do prawdopodobieństwa zgonu $\left(\mathrm{q}_{\mathrm{x}}\right)$ rekonstruowanego w paleodemografii. Przyczyną tej sytuacji jest fakt, że przy stałym natężeniu stresu w pierwszej kolejności umrą osobniki nieprzystosowane do niego, później wśród osobników, które przeżyły, umieralność będzie mniejsza, manifestując się niższym wskaźnikiem prawdopodobieństwa zgonu. Zatem rekonstruowane prawdopodobieństwo zgonu ulegnie zmianie przy stałym natężeniu stresu ${ }^{43}$.

Badania Janusza Piontka ${ }^{44}$ wskazują na podobny poziom stresu środowiskowego wśród populacji z okresu wpływów rzymskich i średniowiecza. Przedstawione wyniki nie wyczerpują jednak problematyki zagadnienia i istnieje wyraźna potrzeba zastosowania pogłębionych analiz bioarcheologicznych cmentarzysk kultury wielbarskiej przy jednoczesnym uwzględnieniu specyfiki kulturowej społeczności wielbarskiej oraz zróżnicowania warunków środowiskowych.

\section{Konkluzja}

Badania paleodemograficzne nad kulturą wielbarską są skomplikowane i niekiedy nie pozwalają na uzyskanie wiarygodnych wyników. Największym problemem, na jaki natrafia badacz, jest utrata danych wynikająca $z$ obrządku ciałopalnego i złego zachowania materiału kostnego. Nie można wykluczyć, że wpływ na utratę danych wejściowych mają również inne zjawiska kulturowe.

Obecnie stosowane metody antropologiczne nie pozwalają na uzyskanie wiarygodnej informacji o strukturze demograficznej populacji, zwłaszcza w przypadku grobów ciałopalnych, a jedynie o płci i wieku pojedynczych osobników, choć nieustanny rozwój procedur badawczych, w tym perspektywiczne wykorzystanie chociażby analiz DNA, w przyszłości może istotnie wpłynąć na stan naszej wiedzy. W połączeniu z grupą osobników, których stan zachowania nie pozwalał na określenie wieku i płci, sprawia to, że badaniom paleodemograficznym umyka niekiedy połowa, a czasem nawet większość populacji. W takim przypadku wnioskowanie na temat struktur paleodemograficznych będzie obciążone znacznym błędem, a budowane interpretacje łatwe do sfalsyfikowania.

Za cenę przyjęcia założenia rozkładu preindustrialnego w profilu demograficznym, przedstawiona w niniejszym artykule metoda pozwala na oszacowanie prawdopodobieństwa zgonu dzieci w najniższych kategoriach wiekowych oraz

\footnotetext{
${ }^{43}$ Wood i in., „The Osteological”, 343-370.

${ }^{44}$ Janusz Piontek, Ludność dorzecza Odry i Wisty od późnej starożytności do średniowiecza. Warunki życia i stan biologiczny (Poznań: Wydawnictwo Instytutu Antropologii UAM, 2014).
} 
daje pewną informację na temat umieralności w latach starszych, zawodzi jednak w przypadku najstarszych osobników. Kluczowe jest tutaj prawidłowe oszacowanie parametrów, na podstawie których budowany jest model - JI, P oraz $\mathrm{a}_{20}$. Zaprezentowana metoda nosi wszystkie zalety oraz wady współczynników, na podstawie których została stworzona, jednakże pozwala na ominięcie problemu niedoszacowania dzieci poniżej 5. roku życia. Niestety, jest ona podatna na niedoszacowanie liczby osobników dorosłych, jak ma to miejsce w przypadku Kowalewka i zdaje się być często spotykane na cmentarzyskach kultury wielbarskiej. W przypadku cmentarzysk birytualnych jest to szczególnie kłopotliwe, gdyż niekiedy znaczna część informacji paleodemograficznej zostaje utracona.

\section{Bibliografia}

\section{Źródła}

Edda Poetycka. Przetłumaczyła ze staroislandzkiego Apolonia Załuska-Strömberg. Wrocław: Zakład Narodowy im. Ossolińskich, 1986.

Saga o Egilu. Przetłumaczyła ze staroislandzkiego Apolonia Załuska-Strömberg. Poznań: Zakład Narodowy im. Ossolińskich, 1972.

\section{Literatura}

Bocquet-Appel, Jean-Pierre, Claude Masset. „Estimateurs en paléodémographie”. L'Homme 17 (1977), 4: 65-90.

Bocquet-Appel, Jean-Pierre, Claude Masset. „Paleodemography: Expectancy and False Hope". American Journal of Physical Anthropology 99 (1996): 571-583.

Budnik, Alicja. „Identyfikacja ludzi na podstawie materiałów szkieletowych - pewność czy prawdopodobieństwo? O możliwościach i ograniczeniach badań”. W: Królowie, biskupi, rycerze i chłopi - identyfikacja zmartych. Funeralia Lednickie - spotkanie 16, red. Wojciech Dzieduszycki, Jacek Wrzesiński, 25-43. Poznań: Wydawnictwo Oddziału Wielkopolskiego SNAP, 2004.

Chmiel, Marta. Społeczność kultury wielbarskiej. Praca doktorska. Instytut Archeologii i Etnologii Polskiej Akademii Nauk, Poznań, 2015.

Chmiel-Chrzanowska, Marta. „Starość w społeczności kultury wielbarskiej”. Przeglad Archeologiczny 64 (2016), 111-131.

Chmiel-Chrzanowska, Marta, Michał Adamczyk. „O śmierci bez przesady: próba zastosowania podejścia technologicznego $\mathrm{w}$ archeologicznych badaniach nad śmiercią". Materiaty Zachodniopomorskie. Nowa Seria 9 (2015), 1: 7-32.

Chudziak Wojciech, red. Wczesnośredniowieczne cmentarzysko szkieletowe w Katdusie (stanowisko 4). Toruń: Wydawnictwo Naukowe UMK, 2010.

Chudziak Wojciech, red. Wczesnośredniowieczny zespót osadniczy w Kałdusie: studia przyrodniczo-archeologiczne. Toruń: Wydawnictwo Naukowe UAM, 2004. 
Coale, Ansley J., Paul Demeny, Barbara Vaughan. Regional Model Life Tables and Stable Population. New York, London, Paris: Academic Press, 1983.

Czarnecka, Katarzyna. Struktura społeczna ludności kultury przeworskiej. Próba rekonstrukcji na podstawie źródet archeologicznych i analizy danych antropologicznych z cmentarzyska. Warszawa: Państwowe Wydawnictwo Rolnicze i Leśne, 1990.

Fahlander, Fredrik. „Subadult or Subaltern? Children as Serial Categories”. W: (Re) Thinking the Little Ancestor: New Perspectives on the Archaeology of Infancy and Childhood, red. Mike Lally, Alison Moore, 1-12. Oxford: British Archaeological Reports, 2011.

Gładykowska-Rzeczycka, Judyta. „Ludność kultury wielbarskiej w świetle dotychczasowych badań antropologicznych". W: Problemy kultury wielbarskiej, red. Tadeusz Malinowski, 163-182. Słupsk: Wyższa Szkoła Pedagogiczna w Słupsku, 1981.

Gładykowska-Rzeczycka, Judyta. „Badania antropologiczne źródłem wiedzy o obrządku pogrzebowym". W: Popiót i Kość. Funeralia Lednickie - spotkanie 4, red. Jacek Wrzesiński, 109-124. Sobótka-Wrocław: Wydawnictwo Oddziału Wielkopolskiego SNAP, 2002.

Halcrow, Siân E., Nancy Tayles. „The Bioarchaeological Investigations of Childhood and Social Age: Problems and Prospects". Journal of Archaeological Method and Theory 15 (2007): 193-197.

Hawkes, Kristen. „The Grandmother Effect”. Nature 428 (2004): 128-129.

Henneberg, Maciej. ,Notes on Reproduction Possibilities of Human Prehistorical Populations". Przegląd Archeologiczny, 41 (1975): 75-89.

Henneberg, Maciej. „Proportion of Dying Children In Paleodemographical Studies: Estimation by Guess or by Methodical Approach". Przegląd Archeologiczny 43 (1977): $105-114$.

Henneberg, Maciej. „Reproductive Possibilities and Estimations of the Biological Dynamics of Earlier Human Populations". Journal of Human Evolution 5 (1976), 1: 41-48.

Henneberg, Maciej, Janusz Ostoja-Zagórski, Janusz Piontek, Jan Strzałko. „Główne założenia teoretyczno-metodyczne oraz możliwości badań biologii populacji pradziejowych w Europie środkowej”. Przeglad Archeologiczny 23 (1975): 187-231.

Jackes, Mary. „Palaeodemography: Problems and Techniques”. W: Skeletal Biology of Past Peoples: Research Methods, red. Shelley R. Saunders, Anne M. Katzenberg, 189-224. New York: Wiley-Liss, 1992.

Jaskanis, Jan, Jerzy Okulicz. „Kultura Wielbarska (faza cecelska)”. W: Prahistoria ziem polskich. T. 5: Późny okres lateński i okres rzymski, red. Jerzy Wielowiejski, 178189. Wrocław, Warszawa, Kraków, Gdańsk: Zakład Narodowy im. Ossolińskich, Wydawnictwo Polskiej Akademii Nauk, 1981.

Lewis, Mary E. The Bioarchaeology of Children. Perspectives from Biological and Forensic Anthropology. Cambridge, New York, Melbourne, Madrid, Cape Town, Singapore, São Paulo: Cambridge, 2007. 
Madyda-Legutko, Renata, Judyta Rodzińska-Nowak, Joanna Zagórska-Telega. „Pochówki dzieci z cmentarzyska kultury przeworskiej w Opatowie, stan. 1, woj. śląskie - próba interpretacji”. W: Dusza maluczka, a strata ogromna. Funeralia Lednickie - spotkanie 6, red. Wojciech Dzieduszycki, Jacek Wrzesiński, 199-215. Poznań: Wydawnictwo Oddziału Wielkopolskiego SNAP, 2004.

Mays, Simon. Archaeology of Human Bones. London - New York: Routledge, 2002.

McCaa, Robert. „Palaeodemography of Americas. From Ancient Times to Colonialism and Beyond". W: The Backbone of History: Health and Nutrition in the Western Hemisphere, red. Richard H. Steckel, Jerome C. Rose, 94-124. Cambridge: Cambridge University Press, 2002.

Pearson, Mike P. The Archaeology of Death and Burial. Phoenix, Mill, Thrupp, Stroud, Gloucestershire: Texas A\&M University Press College Station, 1999.

Perry, Megan A. „Redefining Childhood through Bioarchaeology: Toward Archaeological and Biological Understanding of Children in Antiquity". Archeological Papers of the American Anthropological Association 15 (2005), 1: 89-91.

Piasecki, Edmund. „Cmentarzyska w aspekcie demograficznym”. Przeglad Archeologiczny 37 (1990): 5-51.

Pietrzak, Mirosław. Pruszcz Gdański Fundstelle 10 Ein Gräberfeld der Osywie- und Wielbark-Kultur in Ostpolen. Kraków: Secesja, 1997.

Piontek, Janusz. Ludność dorzecza Odry i Wisty od późnej starożytności do średniowiecza. Warunki życia i stan biologiczny. Monografie Instytutu Antropologii UAM 16. Poznań: Wydawnictwo Instytutu Antropologii UAM, 2014.

Piontek, Janusz. „Wpływ procesu kremacji na morfologię kości szkieletu ludzkiego. Wyniki badań eksperymentalnych". W: Popiół i Kość. Funeralia Lednickie-spotkanie 4, red. Jacek Wrzesiński, 95-108. Sobótka-Wrocław: Wydawnictwo Oddziału Wielkopolskiego SNAP, 2002.

Séguy, Isabelle, Luc Bucheta. Handbook of Palaeodemography. New York: Springer, 2013.

Séguy, Isabelle, Luc Buchet, Arnaud Bringé, Magali Belaigues-Rossard, Paul Beurnier, Nadège Couvert, Carole Perraut. „Model Life Tables for Pre-Industrial Populations: First Application in Palaeodemography". W: Recent Advances in Palaeodemography Data, Techniques, Patterns, red. Jean-Pierre Bocquet-Appel, 83-117. Paryż: Springer, 2008.

Skorupka, Tomasz. Kowalewko 12 cmentarzysko birytualne ludności kultury wielbarskiej (od polowy I w n.e. do początku III w n.e.). Poznań: Muzeum Archeologiczne w Poznaniu, 2001.

Skóra, Kalina. Struktura społeczna ludności kultury wielbarskiej. Łódź: Wydawnictwo IAiE PAN, 2015.

Strzałko, Jan. „Ekologia populacji ludzkich”. W: Ekologia populacji ludzkich. Środowisko człowieka w pradziejach, red. Jan Strzałko, Janusz Ostoja-Zagórski, 11-97. Poznań: Wydawnictwo Naukowe UAM, 1995. 
Strzałko, Jan, Maciej Henneberg, Janusz Piontek. Wstęp do ekologii populacyjnej człowieka. Poznań: Wydawnictwo Naukowe UAM, 1975.

Symes, Steven A., Christopher W. Rainwater, Erinn N. Chapman, Desina Rachael Gipson, Andrea L. Piper. „Patterned Thermal Destruction of Human Remains in Forensic Setting". W: The Analysis of Burned Human Remeins, red. Christopher W. Schmidt, Steven A. Symes, 15-60. Amsterdam, Boston, Heidelberg, London, New York, Paris, San Diego, San Francisco, Singapore, Sydney, Tokyo: Academic Press, 2008.

Watts, Dorothy. Boudicca's Heirs. Women in the Early Britain. London, New York: Routledge, 2005.

Wood, James W., Darryl J. Holman, Kathleen. A. O’Connor, Rebecca J. Ferrell. „Mortality Models for Paleodemography”. W: Paleodemography. Age Distribution from Skeleton Samples, red. Robert D. Hoppa, James W. Vaupel, 129-168. Cambridge: SBEA, 2002.

Wood, James W., George R. Milner, Henry C. Harpending, Kenneth M. Weiss. „The Osteological Paradox: Problems of Inferring Prehistoric Health from Skeletal Samples". Current Anthropology 33 (1992), 4: 343-370.

Woźny, Jacek. „Symbolika śmierci i rytuałów pogrzebowych w kulturach wczesnotradycyjnych na ziemiach polskich”. W: Popiót i Kość. Funeralia Lednickie - spotkanie 4, red. Jacek Wrzesiński, 45-58. Sobótka-Wrocław: Wydawnictwo Wielkopolskiego Oddziału SNAP, 2002.

\section{Problemy i perspektywy badań paleodemograficznych nad kulturą wielbarską na przykładzie cmentarzyska w Kowalewku}

\section{Streszczenie}

W historii badań nad kulturą wielbarską wielokrotnie podejmowano próby analiz paleodemograficznych. Tego typu badania prowadzone na gruncie kultury wielbarskiej polegały przede wszystkim na konstrukcji tablic wymieralności. Krytyka wysuwana w stosunku do tej metody stała się dla nas impulsem do napisania niniejszego artykułu.

Kluczowe w badaniach nad śmiercią jest to, że pracując na fizycznych szczątkach człowieka, staramy się dociekać, w jaki sposób żył i funkcjonował w środowisku, społeczeństwie, kulturze. Pogrzeb i wydarzenia mu towarzyszące niosą ze sobą wiele znaczeń, które współcześnie mogą być nieczytelne. Wynika to zarówno z ograniczeń metodycznych antropologii czy archeologii, jak również z kultury, której symbole zawarte w pochówkach nie zawsze będą dla nas zrozumiałe, a także z naturalnej utraty pewnej puli informacji.

W niniejszej pracy zastosowano metodę zaproponowaną przez I. Séguy i jej zespół, będącą rozwinięciem metody J.P. Bocqueta i C. Masseta. Dzięki niej możliwe stało się oszacowanie prawdopodobieństwa zgonu. Przy opracowaniu metody wykorzystano tablice wymieralności społeczeństw preindustrialnych $\mathrm{z}$ całego świata, pozbawionych dostępu do medycyny. Z uwagi na problem przy określaniu płci dzieci wypracowano 
model oparty na 167 tablicach. Jako dane wejściowe modelu wykorzystano wskaźniki: juvenility index $\left(\mathrm{JI}=\mathrm{D}_{5-14} / \mathrm{D}_{20-\omega}\right), \mathrm{P}\left(\mathrm{P}=\mathrm{D}_{5-19} / \mathrm{D}_{5-\omega}\right)$ oraz średni wiek osobników powyżej 20 roku życia $\left(\mathrm{a}_{20}\right)$.

Analizie poddano birytualne cmentarzysko kultury wielbarskiej w Kowalewku, stanowisko 12 (powiat Oborniki). Zostało ono w całości rozpoznane wykopaliskowo, zatem teoretycznie dysponujemy informacjami o całości populacji. Analogiczną analizę przeprowadzono dla wczesnośredniowiecznego cmentarzyska w Kałdusie, co umożliwiło porównanie wyników ze stanowiska Kowalewko 12 z cmentarzyskiem, na którym zmarłych chowano jedynie w obrządku szkieletowym.

Rezultaty analizy zaprezentowano $\mathrm{w}$ tabeli 1 i zilustrowano wykresami 2 i 3 . Współczynniki wyliczone dla stanowiska $\mathrm{w}$ Kowalewku wynoszą: $\mathrm{JI}=0,286, \mathrm{P}=0,337$ oraz $\mathrm{a}_{20}=34,2$. Prawdopodobieństwo zgonu dzieci w wieku 0-5 lat wynosi $548 \%$ dla populacji stacjonarnej i 490\% dla populacji stabilnej. Prawdopodobieństwo zgonu noworodka $\left(\mathrm{q}_{0}\right)$ wynosi ok. $300 \% \mathrm{w}$ obu modelach, co wydaje się typowe dla populacji preindustrialnych.

Współczynniki JI oraz P obliczone dla stanowiska w Kowalewku są wysokie w porównaniu do danych modelowych dla $\mathrm{e}_{0}=20$ lat (model „West”) wynoszących 0,16 . Wysoka wartość może być wynikiem znacznego wzrostu populacji, jest jednak również spotykana w przypadku profili katastroficznych. Może być to również skutek niedoszacowania populacji, w przypadku kultury wielbarskiej - przede wszystkim niższej liczby mężczyzn niż kobiet.

Slowa kluczowe: paleodemografia, kultura wielbarska, metody badań, bioarcheologia

\section{Problems and Prospects of Palaeodemographic Research on the Wielbark Culture Exemplified with the Kowalewko Burial Site}

\section{Summary}

In the history of the research into the Wielbark Culture there have been numerous attempts to use palaeodemographic analyses. In most cases, that kind of analysis applied to the Wielbark Culture consisted in constructing mortality tables. Reservations about that method were an impulse for the authors to write the present article.

The key element in the research on human beings' physical remains, i.e. on death, is to find out how they lived and functioned in their environment, society, culture. The funeral and its rites convey a lot of meanings, which nowadays might be illegible. It results from methodological limitations of archaeology or anthropology, from the culture the symbols of which contained in the burials are not always clear, and from a loss of a certain amount of information.

In the present article the authors have used the method suggested by I. Séguy and her team, which is an extension of the method of J. P. Bocquet and C. Masset. Thanks to that it has been possible to assess the probability of death. The method comprises the mortality tables of pre-industrial societies with no access to health care system from all over 
the world. On account of the difficulty in indicating the sex of children, a new model has been created that is based on 167 tables; as its input data the following indices have been used: juvenility index $\left(\mathrm{JI}=\mathrm{D}_{5-14} / \mathrm{D}_{20-\omega}\right), \mathrm{P}\left(\mathrm{P}=\mathrm{D}_{5-19} / \mathrm{D}_{5-\omega}\right)$ and the average age of people over 20 years old $\left(\mathrm{a}_{20}\right)$.

The authors have analysed site 12 (Oborniki County) of the biritual burial grounds of the Wielbark Culture. The site has been comprehensively researched, so theoretically there is a complete picture of the population. The early medieval burial site in Kałdus has been analysed in the similar way, which made it possible to compare the results of site no 12 with the cemetery where only the skeleton rite was used.

The results have been presented in Table 1 and illustrated with Diagrams 2 and 3. The indices for the site in Kowalewko are: $\mathrm{JI}=0.286 ; \mathrm{P}=0.337$; and $\mathrm{a}_{20}=34.2$. The probability of children's death aged $0-5$ years is $548 \%$ or the stationary population and $490 \%$ for the stable population. The probability of a newborn's death is about $300 \%$ in both models, which seems typical of the pre-industrial populations.

The indices $\mathrm{JI}$ and $\mathrm{P}$ for the site in Kowalewko are quite high in comparison to the model data of $\mathrm{e}_{0}=20$ years (Model 'West'), which equals 0.16 . The high value may result from a significant increase in population, but it also occurs in catastrophic profiles. It may also be a result of underestimating the population, in the case of the Wielbark Culture - by an inferior number of men compared to women.

Higher values of these coefficients may be the result of a significant increase of fertility or catastrophic events. They also can be a result of underestimating the number of individuals on the cemetery. It allows to bypass the problem of underestimation of children. In the case of the Wielbark Culture it seems that part of the males were buried outside the cemetery or in a way that does not allow a credible anthropological analysis (for example cremation). The disproportion between the number of women and men indicates a significant underestimation of the adults on the cemetery in Kowalewko.

The differences in results of probability of death between the sites in Kowalewko and Kałdus can be explained by different fertility or environmental stress. However, it seems more likely that they are the result of disturbances in the representation of different age categories on the cemeteries.

Palaeodemographic research on the Wielbark Culture is very difficult and it is not always possible to obtain reliable results. The main problems of that kind of research include poor state of bones preservation, cremation and cultural influences. As an effect in palaeodemographic research we miss a big part of the population. As a consequence, the conclusions about palaeodemographic structures may contain errors.

Keywords: palaeodemography, Wielbark culture, research methods, bioarchaeology 